\title{
Effects of Food Deprivation in Muscle Structure and Composition of Traíra (Hoplias malabaricus): Potential Implications on Flesh Quality
}

\author{
Flavia Sant'Anna Rios ${ }^{1 *}$, Lucélia Donatti ${ }^{1}$, Marisa Narciso Fernandes ${ }^{2}$, Ana Lucia Kalinin ${ }^{2}$, \\ and Francisco Tadeu Rantin ${ }^{2}$ \\ ${ }^{1}$ Departamento de Biologia Celular; Centro Politécnico; Universidade Federal do Paraná; C. P.: 19031; 81531- \\ 970; Curitiba - PR - Brasil. ${ }^{2}$ Departamento de Ciências Fisiológicas; Universidade Federal de São Carlos; Via \\ Washington Luiz, km 235; 13565-905; São Carlos - SP - Brasil
}

\begin{abstract}
Hoplias malabaricus (traíra) were experimentally starved (0 to 240 days) and subsequently re-fed for 30 days (after 90 and 240-d fasting). Long-term starvation produced minor changes in muscle composition, but shrinkage of muscle fibres was a conspicuous result. The diameter of muscle fibres decreased gradually and the spaces among them increased as the starvation period progressed. After re-feeding, fish prior starved for 90 days presented partial restoration on diameter of muscle fibres. However, the fibres remained shrunken after re-feeding following 240-d fasting. While the lipid content did not change, the protein levels fell after 240-d fasting, but they were restored after re-feeding
\end{abstract}

Key words: fish, morphology, muscle, proximate composition, starvation

\section{INTRODUCTION}

Sustainable development of aquaculture is dependent on the diversity and quality of products (Toussaint et al. 2005). Flesh quality is becoming of increasing concern to fishing and aquaculture industry as the total production increases. It is usually defined in terms of appearance, taste, smell, firmness, texture, juiciness and process characteristics (Johnston, 1999).

The main edible part of the fish is composed of white muscle fibres. The flesh quality may be influenced by extrinsic factors such as feeding regime, diet composition, and environment (Johnston, 1999; Johnston et al., 2000). The biochemical composition, particularly lipids, may change the nutritional and sensorial quality of fish flesh (Waagabo et al., 1993; Arzel et al., 1994; Regost et al., 2001). The number and size distribution of fibres (muscle cellularity) is known to be a major determinant of flesh texture (Hatae et al., 1990; Fauconneau et al., 1993; Hurling et al., 1996). A major future goal of research in this field is to establish the relationship between the muscle cellularity, texture, taste and processing characteristics (Johnston, 1999).

\footnotetext{
* Author for correspondence: flaviasrios@ufpr.br
} 
Pantanal of Mato Grosso (Brazil) is the largest tropical wetland area in the world. It presents extreme fluctuations in rainfall regime and droughts may last until six months (Hamilton et al., 1996; 1998; Britzki et al., 1999). Fishing is more intensive during the ebb and drought seasons, when the high density of fish in the temporary ponds facilitates their catch (Resende $e t$ al., 1996; Oliveira and Nogueira, 2000). Traíra (Hoplias malabaricus Bloch, 1794) represents about $25 \%$ of ictiofauna of these ponds (Bonetto et al., 1969) and has been the most frequent (59.4\%) species captured for human consumption (subsistence fishing) in the Pantanal of Mato Grosso (Oliveira and Nogueira, 2000), representing an important source of protein to local population.

Limited food supply during a severe drought may potentially change the flesh proprieties. Starvation adversely affects the overall physiological condition such as fish health and muscle quality as food (Durazo-Beltrán et al., 2004), changing the physical and organoleptic flesh quality (Einen et al., 1998; Einen and Thomassen, 1998). Since traíras usually starve in the main fishing season, due to which the nutritional and quality characteristics of muscles may be altered. The present study was carried out to determine the changes in the structure of muscle fibres and biochemical composition (total lipids and protein) of white muscle of traíra due to increased starvation period and after re-feeding.

\section{MATERIAL AND METHODS}

Ninety wild traíra were assigned at random to nine groups ( $\mathrm{n}=10$ per group). Fishes were kept in 500 $\mathrm{L}$ indoors tanks, supplied with constantly running water at $25 \pm 1^{\circ} \mathrm{C}$. The photoperiod was 12L:12D. During acclimation (20-30 days), they were fed $a d$ libitum on small live fishes. At the end of acclimation period, all the fishes were individually weighed $(251.7 \pm 6.5 \mathrm{~g}$, mean $\pm \mathrm{SEM})$, and sized $(23.5 \pm 0.19 \mathrm{~cm}$, mean \pm SEM $)$. They were then fed a ration corresponding to $2 \%$ of biomass day ${ }^{-1}$ for 30 days. Afterwards, a sample of 10 fishes was taken (control group) for muscle composition and structural analysis. Six groups were then deprived of food for $30,60,90,150,180$, and 240 days, respectively. The two remaining groups were re- fed (2\% of biomass day-1) for 30 days following 90 and 240 days of food deprivation, respectively.

After the treatments, fishes were weighed, sized and killed by rapid decapitation. Samples of white muscle (epaxial muscle) were excised, washed with $0.9 \% \mathrm{NaCl}$ and fixed in Bouin fluid (Culling et al., 1985) for $24 \mathrm{~h}$ at room temperature. The samples were dehydrated in a crescent gradual series of ethanol and embedded in Paraplast Plus. Tissue sections were routinely stained with hematoxylin and eosin (HE; Clark, 1981). Crosssectional areas of muscle fibres were measured using Sigma Scan software (v. 3.0, Jandel Scientific). Four hundred fibres of each experimental treatment were randomly analysed.

For biochemical analysis, samples of epaxial muscle were removed, weighed and kept at $-80^{\circ} \mathrm{C}$. Total lipids were extracted with chloroformmethanol (2:1) and quantified gravimetrically (Folch et al., 1957). Total protein was determined according to Lowry et al. (1951).

The normal distribution of variables was tested using the Bartlett's test for homogeneity of variances. One-way analysis of variance (ANOVA), complemented by the Tukey-Kramer multiple comparisons test, were employed to analyse the data (GraphPad Instat - GraphPad Software Version 3.0). Data were expressed as means \pm SEM and considered significantly different when $\mathrm{P}<0.05$.

\section{RESULTS}

Final whole-body mass declined gradually as starvation progressed. The weight loss became significantly higher up to 90 days of food deprivation (Fig 1). Re-fed fishes from both the groups gained some weight. However, this gain was significant in fishes prior to starvation for 90 days $(14.81 \%, \mathrm{p}<0.05)$, but not significant in fishes prior starved for 240 days $(8.40 \%)$. The cross-sectional areas of muscle fibres reduced progressively with increasing starvation time (Figs. 2 and 3). Under all periods of fasting (30, $60,90,150,180$ and 240 days), fishes presented fibres with diameter smaller than both, the control $(\mathrm{p}<0.001)$ and preceding groups $(\mathrm{p}<0.05)$. The re-fed fishes following 90-d fasting presented fibres thicker than the respective fasting group $(\mathrm{p}$ $<0.001)$, but remained smaller than control ( $\mathrm{p}<$ $0.001)$. On the other hand, the cross-sectional 
areas of muscle fibres, after re-feeding following 240-d fasting remained similar to the respective starved group ( $\mathrm{p}<0.001)$, and consequently, smaller than in control group $(\mathrm{p}<0.001)$.

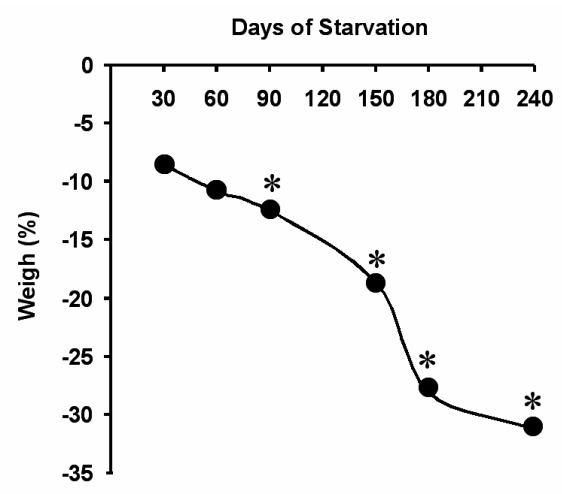

Figure 1 - Weight loss of Hoplias malabaricus during long-term starvation. Tukey-Kramer multiple comparisons test: significance of the differences vs. control group values: $*=$ $\mathrm{p}<0.05$.

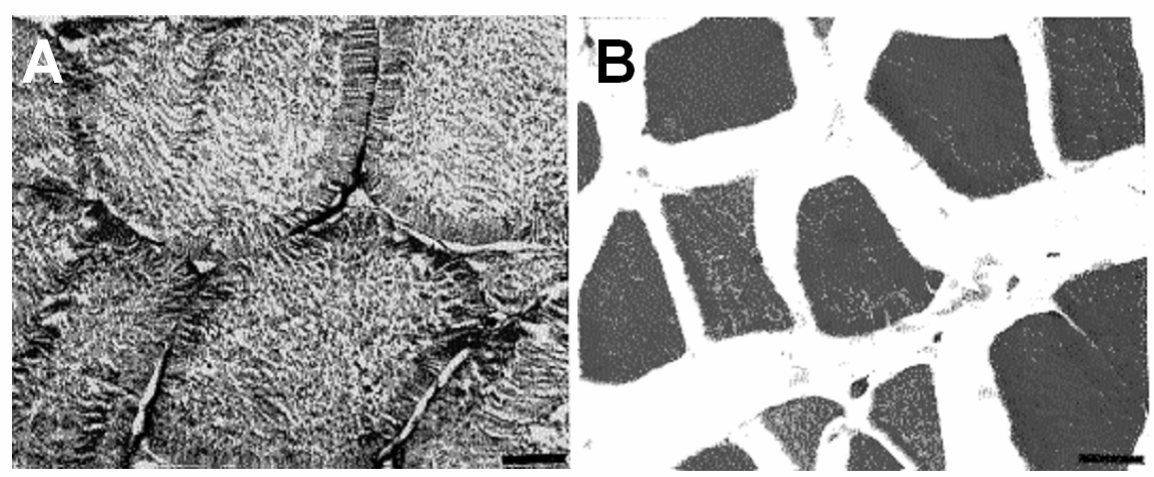

Figure 2 - Transverse section of epaxial muscle of Hoplias malabaricus: (A) fed (control), and (B) starved for 240 days. Scale bar is $10 \mu \mathrm{m}$.

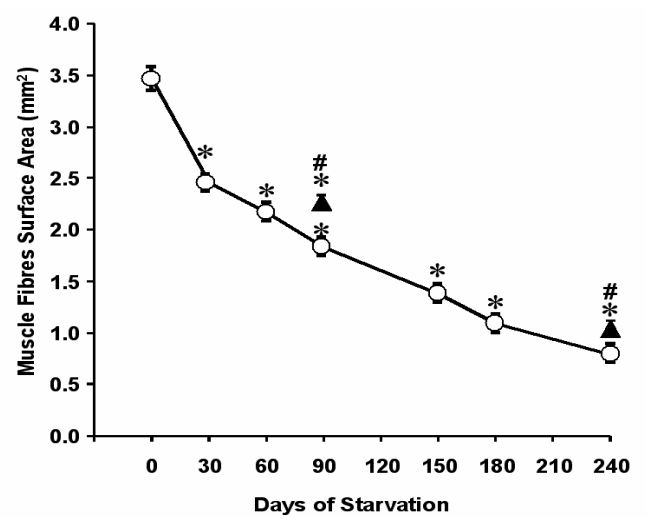

Figure 3 - Surface area of white muscle fibres $\left(\mathrm{mm}^{2}\right)$ in Hoplias malabaricus during long-term starvation. $\mathbf{O}=$ Starved fish $\boldsymbol{\Delta}=$ Re-fed fish. Values are expressed as mean $\pm \mathrm{SEM}$. Tukey-Kramer multiple comparisons test: significance of the differences vs. Control and preceding groups values: $*=p<0.05$; differences between re-fed fish vs. Values of the respective starved group: $\#=p<0.05$. 
Following 180- and 240-d fasting, the spaces among fibres were visually larger than control and preceding groups. Muscle protein concentration decreased $(\mathrm{p}<0.05)$ after $240-\mathrm{d}$ fasting and it was restored after re-feeding (Fig. 4). Lipid concentration remained unchanged after fasting and re-feeding (Fig. 4).

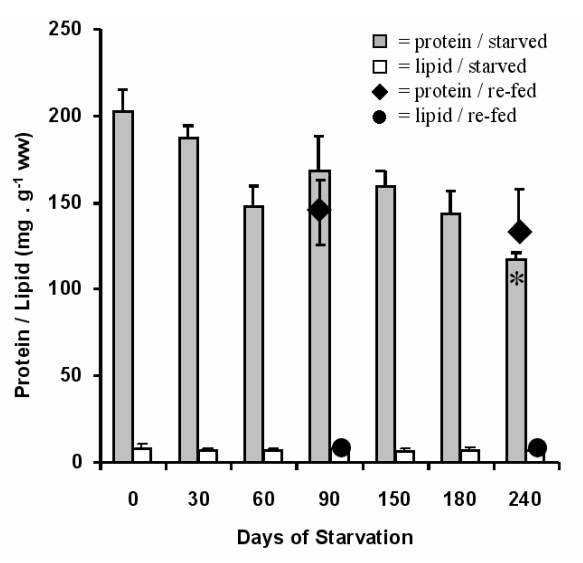

Figure 4 - Total lipid ( $\mathrm{mg} \mathrm{g}^{-1}$ wet weight) and total protein ( $\mathrm{mg} \mathrm{g}^{-1}$ wet weight) in starved and refed Hoplias malabaricus during long-term starvation. Values are expressed as mean \pm SEM. Tukey-Kramer multiple comparisons test: significance of the differences vs. Control values: $*=p<0.05$.

\section{DISCUSSION}

The fishes weight loss was along with the narrowing of muscle fibres, showing that there was a progressing loss of muscle mass during food deprivation. Shrinkage of white muscle fibres is a common effect of starvation in fish, reflecting the intense protein utilization (Greer-Walker, 1971; Love, 1980; Moon, 1983; Love, 1988). An increase in protease activity within muscle tissue was associated with the utilization of tissue protein (Durazo-Beltrán et al., 2004).

After long-term food deprivation, proteins are frequently the main energy source (e.g. Black and Love, 1986). In traíra, protein mobilization was noticeable after 60 days of fasting, and became the major energy sourcel between 90 and 180 days of food deprivation (Rios et al., 2006). This was consistent with the present results: a gradual decrease in the surface area of fibres. Nevertheless, following the longest periods of food deprivation (240 days), the main substrate was shifted to the conserved hepatic glycogen (Rios et al., 2006), probably to avoid irreversible damages to the muscle structure. The removal of high amounts of protein from white muscle fibres may impair muscle function, mainly in burst swimming s200 pecies (Kiessling et al., 1993) as traíra. In the present study, the decreasing in muscle protein concentration after 240 days and the presence of fibres smaller than that observed after 180 days could be a consequence of protein utilisation between 180 and 240 days (period not evaluated). In traíra, the decreased protein level after 240-d of food deprivation suggested that nutritional value could be little altered when compared to fed fishes.

The variation in muscle cellularity and associated changes in connective tissue matrix are thought to be important determinants of texture and other flesh quality characteristics (Johnston, 1999). During starvation, fishes use the contract and soluble proteins as energy source, while the connective tissue is hardly mobilized (Love, 1980). Hence, the collagen proportion tends to increase with food deprivation. Johnston et al. (2000) related the muscle fibres density of Atlantic salmon (Salmo salar) with the flesh texture and concluded that a potential manipulation of muscle cellularity through husbandry practices and selective breeding programs could improve fish flesh.

Instrumental texture analyses indicated that longterm starvation (58 days or more) could increase 
the hardness of raw fillets after starvation, whereas the sensory analyses indicated that long-term starvation (86 days) decreased the hardness of cooked fillets (Einen et al., 1998). For cooked flesh, sensory firmness determined using a trained panel was negatively correlated with average muscle fibre cross-sectional area in seven species of marine fish (Hurling et al., 1996). Hatae et al. (1990) suggested that narrow diameter fibres had a higher intrinsic strength due to 'scaling effects'. Among different fish species, there was a significant correlation between collagen content and the flesh firmness of the raw fish but not of the cooked flesh due to the denaturation of the collagen (Hatae et al., 1986). Following cooking, the muscle fibres themselves constitute the main elements of resistance to mastication (Dunajski, 1979).

The enlarged spacing among muscle fibres is correlated to the increased water content in the muscle of starved fishes (Love, 1970; 1980). The lipid and water content of the muscle and the geometrical characteristics of the fibres are both thought to contribute to the 'juiciness' of the fish in organoleptic tests (Dunajski, 1979). Since water contributes to the proliferation of microorganisms and lipid content is related to oxidation in flesh, their augmentation reduces the storage stability. Lipid content is an important aspect affecting the flesh taste in many species (Robb et al., 2002). But in view of the fact that traíra was a lean fish and the fat content did not vary significantly during the experiments, the taste might not be changed due to food deprivation. Although lipid concentration did not alter, the changes on moisture might modify the 'juiciness' and decrease storage stability as starvation time progressed. The water content was not quantified in the present study, but the increasing spacing showed by histology suggested an increase in moisture proportion.

Re-feeding seemed to re-establish partially the quality of traíra's muscle. Re-fed traíra following 90 days of starvation restored partially the fibres surface area, while fishes prior starved for 240 days did apparently not recover the fibres size after re-feeding. However, fibres spacing seemed smaller in these fishes, suggesting that new fibres with small diameter should be added (hyperplasic growth).

\section{ACKNOWLEDGEMENTS}

We sincerely thank to Dr. Edith S. E. Fanta (UFPR, Curitiba, PR) for laboratory facilities, to Douglas Viana for technical support, and to Nelson S. A. Matos (in memoriam) for collecting the fishes. This work was supported by FAPESP (Proc. 98/06737-3).

\section{RESUMO}

Efeito da alimentação na estrutura e composição bioquímica muscular da traíra (Hoplias malabaricus): potenciais implicações para a qualidade da carne. Diferenças na alimentação podem alterar a composição química a organização das fibras musculares dos peixes.. Hoplias malabaricus (traíra) é uma das principais espécies capturadas pela pesca de subsistência no Pantanal Matogrossense. O objetivo deste estudo foi estimar as possíveis alterações na qualidade da carne após os longos períodos de privação de alimento que esta espécie enfrenta anualmente. Indivíduos adultos foram privados de alimento experimentalmente por $0,30,60,90,150,180 \mathrm{e}$ 240 dias, e, em seguida, re-alimentados por 30 dias (após 90 e 240 dias de jejum). O jejum em longo prazo parece ter produzido pequenas alterações na composição química do músculo da traíra, mas a redução do diâmetro das fibras musculares foi evidente. $\mathrm{O}$ diâmetro das fibras musculares reduziu gradualmente e os espaços entre elas aumentaram proporcionalmente ao tempo de privação de alimento. Após a realimentação, os peixes que haviam sido privados de alimento por 90 dias apresentaram um aumento no diâmetro das fibras musculares, mas elas permaneceram menores que no grupo controle. No entanto, não houve aumento do diâmetro das fibras nos peixes re-alimentados após 240 dias de jejum. Não houve alteração no conteúdo de lipídios, mas ocorreu a diminuição da concentração de proteínas após 240 dias de jejum a qual foi recuperada após a alimentação. Os resultados foram discutidos com ênfase na qualidade da carne. 


\section{REFERENCES}

Arzel, J.; Martinez Lopez, F. X.; Metailler, R.; Stephan, G.; Viau, M.; Gandemer, G.; Guillaume, J. (1994), Effect of dietary lipid on growth performance and body composition of brown trout Salmo trutta reared in seawater. Aquaculture, 123, 361-375.

Black, D.; Love, M. R. (1986), The sequential mobilisation and restoration of energy reserves in the tissues of Atlantic cod during starvation and refeeding. J. Comp. Physiol. 156B, $469-479$.

Bonetto A. A.; de Yuan, E. C.; Pignalberi, C.; Oliveiros, O. (1969), Ciclos hidrológicos del Río Paraná y las poblaciones de peces contenidas en las cuencas temporarias de su valle de inundación. Physis, 29, 213-223.

Britzki, H. A.; Silimon, K. Z. S.; Lopes, B. L. (1999), Peixes do Pantantal: Manual de identificação. Embrapa, Brasília.

Clark, G. (1981), Staining Procedures. Williams and Wilkins, Baltimore

Culling, C. F. A.; Allison, R. T.; Barr, W. T. (1985), Cellular Pathology Technique. Butterworth., London

Durazo-Beltrán, E.; Viana, M. T.; D’Abramo, L. R.; Toro-Vazquez, J. F. (2004), Effects of starvation and dietary lipid on the lipid and fatty acid composition of muscle tissue of juvenile green abalone (Haliotis fulgens). Aquaculture, 238, 329-341.

Dunajski, E. (1979), Texture of fish muscle. J. Texture Studies, 10, 301-318.

Einen, O.; Thomassen, M.S. (1998), Starvation prior to slaughter in Atlantic salmon Salmo salar: II. White muscle composition and evaluation of freshness, texture and colour characteristics in raw and cooked fillets. Aquaculture, 169, 37-53.

Einen, O.; Waagen, B.; Thomassen, M. S. (1998), Starvation prior to slaughter in Atlantic salmon Salmo salar : I. Effects on weight loss, body shape, slaughter and fillet-yield, proximate and fatty acid composition. Aquaculture, 166, 85-104.

Fauconneau, B.; Chmaitilly, J.; Andre, S.; Cardinal, M.; Cornet, J.; Vallet, J. L.; Dumon, J. P.; Laroche, M. (1993), Caractéristiques de la chair de truite arc en ciel: II. Composantes physiques et sensorielles. Sci. Alim., 13, 188-199.

Folch, G. D.; Lees, M.; Sloane-Stanley, G. H. (1957), A simple method for the isolation and purification of total lipids from animal tissues. J. Biol. Chem., 226, $497-509$.

Greer-Walker, M. (1971), Effect of starvation and exercise on the skeletal muscle fibres of the cod (Gadus morhua L.) respectively. J. Cons. Internat. l'explor. Mer, 33, 421-426.

Hamilton, S. K.; Sippel, S. J.; Melack, J. M. (1996), Inundation patterns in the Pantanal wetland of South America determined from passive microwave remote sensing. Arch. Hidrobiol., 137, 1-23.
Hamilton, S. K.; Souza, O. C.; Coutinho, M. E. (1998), Dynamics of floodplain inundation in the alluvial fan of the Taquari River (Pantanal, Brazil). Verh . Internat. Verein. Limnol., 26, 916-922

Hatae, K.; Tobimatsu, A.; Takeyama, M.; Matsumoto, J.J. (1986), Contribution of the connective tissues on the texture differences of various fish species. Bull. Jpn. Soc. Sci. Fish., 52, 2001-2008.

Hatae, K.; Yoshimatsu, F.; Matsumoto, J.J. (1990), Role of muscle fibres in contributing firmness of cooked fish. J. Food Sci., 55, 693-696.

Hurling, R.; Rodell, J. B.; Hunt, H. D. (1996), Fibre diameter and fish texture. J. Texture Studies, 27, 679685.

Johnston, I. A.; Alderson, R.; Sandham, C.; Dingwall, A.; Mitchell, D.; Selkirk, C.; Nickell, D.; Backer, R.; Robertson, B.; Whyte, D.; Springate, J. (2000), Muscle fibre density in relation to the colour and texture of smoked Atlantic salmon (Salmo salar L.). Aquaculture, 189, 335-349.

Johnston, I. A. (1999), Muscle development and growth: potential implications for flesh quality in fish. Aquaculture, 177, 99-115.

Kiessling, A.; Hung, S. S. O.; Storebakken, T. (1993), Differences in protein mobilization between ventral and dorsal parts of white epaxial muscle from fed, fasted and refed white sturgeon (Acipenser transmontanus). J. Fish Biol., 43, 401-408.

Love, R. M. (1970), The Chemical Biology of Fishes. vol. I. Academic Press, London.

Love, R. M. (1980), The Chemical Biology of Fishes, vol. II. Academic Press, London.

Love, R. M. (1988), The Food Fishes: Their Intrinsic Variation and Practical Implications. Ferrand Press, London.

Lowry, O. O.; Rosebrough, N. J.; Farr, A. L.; Randall, R.J. (1951), Protein measurement with the Folin phenol reagent. J. Biol. Chem., 193, 265 - 275.

Moon, T. W. (1983), Changes in tissue ion content and ultrastructure of food deprived immature American eels, Anguilla rostrata (LeSueur). Can. J. Zool., 61, 812-821.

Oliveira, R. D.; Nogueira, F. M. de B. (2000), Characterization of the fishes and of subsistence fishing in the Pantanal of Mato Grosso, Brazil. Rev. Bras. Biol., 60, 435-445.

Regost, C.; Arzel, J.; Cardinal, M.; Robin, J.; Laroche, M.; Kaushik, S. J. (2001), Dietary lipid level, hepatic lipogenesis and flesh quality in turbot Psetta maxima. Aquaculture, 193, 291-309.

Resende, E. K.; Pereira, R. A. C.; Almeida, V. L. L.; Silva, A. G. (1996), Alimentação de peixes carnívoros da planície inundável do Rio Miranda, Pantanal, Mato Grosso do Sul, Brasil. EMPRAPACPAP, Corumbá.

Rios, F. S.; Moraes, G.; Oba, E. T.; Fernandes, M. N.; Donatti, L.; Kalinin, A. L.; Rantin, F. T, (2006), Mobilization and recovery of energy stores in traíra, 
Hoplias malabaricus Bloch (Teleostei, Erythrinidae) during long-term starvation and re-feeding. J. Comp. Physiol., 176B, 721-728.Robb, D. H. F.; Kestin, S. C.; Warriss, P. D.; Nute, G. R. (2002), Muscle lipid content determines the eating quality of smoked and cooked Atlantic salmon (Salmo salar). Aquaculture, 205, 345-358.

Toussaint, C.; Fauconneau,B.; Médale, F.; Collewet, G.; Akoka, S.; Haffray, P.; Davenel, A. (2005), Description of the heterogeneity of lipid distribution in the flesh of brown trout (Salmo trutta) by MR imaging. Aquaculture, 243, 255- 267
Waagbø, R.; Sandnes, K.; Torrissen, O. J.; Sandvin, A.; Lie, Ø. (1993), Chemical and sensory evaluation of fillets from Atlantic salmon Salmo salar fed three levels of ny3 fatty acids at two levels of vitamin E. Food Chem., 46, 361-366.
Received: March 28, 2006; Revised: February 01, 2007; Accepted: December 23, 2008. 